doi: $10.26529 /$ cepsj.491

\title{
Taxonomy of Teaching Methods and Teaching Forms for Youth in Non-Formal Education in the National Youth Council of Slovenia
}

Vesna MilošEvič Zupančič ${ }^{1}$

$\approx$ Research from the field of non-formal education (NFE) in youth work emphasises the central role of experiential learning and learning in groups. The present paper aims to research teaching methods and teaching forms in NFE in youth work. The research sought to answer the following research questions: 'What teaching forms can be found in NFE for young people in youth councils on a national level in Slovenia?' and 'What teaching methods can be found in NFE for young people in youth councils on a national level in Slovenia?' Data was collected using semi-structured interviews; the instrument was a list of questions. The empirical research was conducted in July 2016 with six interviewees. The results indicate that learning in selected NFE in the National Youth Council of Slovenia (MSS) is participatory, interactive, inclusive and student-focused; with central concepts of experiential learning and learning in groups. The key teaching form is learning in groups. However, individual work, work in pairs, programmed instruction and direct instruction are also present. The central and omnipresent teaching method is experiential learning. Problem-based learning, case-study method, action learning, and project-based learning are intertwined and connected to the experiential learning method. Other methods include verbal-textual methods, illustrative-demonstration methods, experimental methods, peer learning, and support methods. The conclusions are applicative in the didactic spectrum of NFE in youth work and in the wider didactic spectrum of adult learning. Implications for further research include teaching methods and forms in NFE inside the wider youth sector, internationally comparative and through quantitative research.

Keywords: non-formal education, teaching forms, teaching methods, youth organisations, youth work 


\section{Taksonomija učnih metod in oblik za mlade $\mathrm{v}$ neformalnem izobraževanju v Mladinskem svetu Slovenije}

Vesna MilošEvič Zupančič

$\approx$ Raziskave s področja neformalnega izobraževanja (NFI) v mladinskem delu poudarjajo osrednjo vlogo izkustvenega učenja in dela v skupinah. Cilj tega prispevka je raziskati učne metode in oblike v NFI v mladinskem delu. Raziskava je poskušala odgovoriti na naslednji raziskovalni vprašanji: »Katere učne oblike obstajajo v NFI za mlade v mladinskih svetih na nacionalni ravni v Sloveniji? « in »Katere učne metode obstajajo v NFI za mlade v mladinskih svetih na nacionalni ravni v Sloveniji?«. Podatki so bili zbrani s pol-strukturiranimi intervjuji, pri čemer je bil instrument seznam vprašanj. Empirična raziskava je bila izvedena v juliju 2016 s šestimi intervjuvanci. Izsledki kažejo, da je učenje v izbranih NFI v Mladinskem svetu Slovenije (MSS) participativno, interaktivno, vključujoče in osredinjeno na učenca - z osrednjimi koncepti izkustvenega učenja in dela v skupinah. Osrednja učna oblika je učenje v skupinah. Prisotne pa so tudi druge posredne učne oblike: individualno delo, delo $\mathrm{v}$ dvojicah in programirani pouk ter neposredna oz. frontalna učna oblika. Prevladujoča in vseprisotna učna metoda je izkustveno učenje. Problemska metoda, metoda primera, akcijsko učenje in projektna metoda so prepleteni in se povezujejo z izkustvenim učenjem. Preostale metode vključujejo verbalno-tekstualne metode, ilustrativno-demonstracijske metode, laboratorijsko-eksperimentalne metode, vrstniško učenje in podporne metode. Zaključki so aplikativni v didaktičnem spektru NFI v mladinskem delu in širšem didaktičnem spektru izobraževanja odraslih. Predlogi za nadaljnje raziskovanje vključujejo učne metode in oblike v NFI znotraj širšega mladinskega sektorja, primerjavo na mednarodni ravni in dopolnitev s kvantitativno raziskavo.

Ključne besede: neformalno izobraževanje, učne oblike, učne metode, mladinske organizacije, mladinsko delo 


\section{Introduction}

Subjective perceptions of learning might bring the first association to the learning in the formal educational system, referred to as formal learning. However, youth organisations are places that offer young people the other two categories of learning: non-formal learning and informal learning. Non-formal education (NFE) and training together with boosting the competencies of young people are within the key scopes of organisations in the youth sector.

The field of youth work is highly interdisciplinary, connecting several scientific disciplines, including pedagogy, social work, and political science. The concept of youth work is polyvalent, multifaceted, heterogeneous, and has no unified definition (Coussée, 2009; Pantea, 2012). It can be described as a reaction to the processes of exclusion, alienation, and disintegration of modern societies (Kuhar \& Razpotnik, 2011). In Slovenia, youth work can be defined as a form of work with young people, which is voluntary, encouraging active citizenship, fostering social integration and consciously containing educational components (Kuhar \& Leskošek, 2008). Youth organisations are civil society organisations that are non-profit, private, and formal. As such, they can be located in the part of social reality between the community, the state, and the market (Kolarič \& Rakar, 2010). It is said that the role of citizens and civil society shall be reconsidered in an attempt to widen democratic participation (Gaber \& Mojškerc, 2014). The majority of Western democracies encourage youth participation as a part of the debate on modern citizenship (Bessant, 2004), the result of which is the formation of youth councils, youth assemblies, and other decision-making or consulting bodies (Taft \& Gordon, 2013). Rakar et al. (2011) divide youth organisations in Slovenia, among others, into the National Youth Council of Slovenia (MSS), youth councils of local communities, youth centres, national youth organisations, and other non-governmental organisations.

There are both non-formal learning and informal learning in youth organisations (European Commission, 2000, 2012). Learning is a broad concept, defined by several theories in psychology (Marentič-Požarnik, 2014), sociology (Haralambos \& Holborn, 2005) and other disciplines (e.g., economy), with the official definition by UNESCO/ISCED (Marentič-Požarnik, 2014, p. 10-19; UNESCO, 1993, p. 2). Regarding the situation in which learning takes part, we can divide learning into three categories (Žagar \& Kelava, 2014). Formal learning is a highly institutionalised and structured process; informal learning is an activity that takes place in everyday life (Boeren, 2011), it is not institutionalised, and it can be self-, family- or socially-directed (Lebeničnik, Pitt, \& Starčič Istenič, 2015). Lastly, non-formal learning can be defined as 'organized 
education taking place outside the formal education system' (Boeren, 2011, p. 335). It can inter alia take place within civil society organisations such as youth organisations (European Commission, 2000).

Within the concept of learning, the present paper focuses on a didactic aspect, on teaching methods and teaching forms. ${ }^{2}$ Teaching methods can be defined as theoretically justified and empirically tested modes of action, through which the subjects of the educational/learning processes implement their aims and objectives (Kramar, 2009). Modern didactics and educational psychology divide them into student-focused and teacher-focused methods (Radovan, 2013). Teacher-focused methods emphasise information transmission, whereas student-focused methods emphasise the conceptual change (Stes \& Petegem, 2014). Constructivist theories of learning emphasise the shift in focus from conventional lectures to teaching methods that activate the learner and are student-focused (Struyven, Dochy, \& Janssens, 2010). Active teaching methods include case-study, problem-based learning, collaborative assignments (Struyven et al., 2010), participatory learning, experiential learning, peer learning, and project-based learning (Javornik Krečič, Rutar Leban, \& Kelava, 2014). Problem-based learning is defined as learning where students work in groups to resolve complex, real(istic) problems under guidance (Allen, Donham, \& Berhhard, 2011), and it is considered more interesting and efficient than classic academic presentations (Gojkov, Stojanović, \& Gojkov-Rajić, 2015). Similarly, project-based learning can be defined as learning in groups under guidance to research and create projects (Bell, 2010). The cognitive-constructivist model overcomes the division of teacher-focused and student-focused methods, thereby stressing the construction of knowledge in the interaction between both sides (Javornik Krečič et al., 2014). The teaching process is a communication process by its nature; therefore, teaching methods can be classified according to the source by which the message comes to the learner (Tomić, 200o). Classification by the source divides teaching methods into the verbaltextual method (spoken explanation method; conversation method; working with texts), the illustrative-demonstration method, the experimental method, and the experiential learning method (according to Kolb) (Tomić, 200o). Based on Jarvis, experiential learning originates in primary experiences, and it can be defined as learning through activity, which differentiates it from passive

2 The concept of teaching methods is often semantically broader in the context of English-speaking countries and it includes the notions of teaching forms. However, in the German-speaking countries (e.g., Germany) and in countries of ex-Yugoslavia (e.g., Slovenia, Croatia), there is a division in didactics to teaching methods and teaching forms. As the paper aims to encompass all the didactic aspects of NFE in youth organizations in the geographical context of Slovenia, the author follows the division of teaching methods and teaching forms. 
learning through the reception of information (Timm, Birkenmaier, \& Tebb, 2011). Kolb's experiential learning is based on a circular model with four phases: concrete experience, reflective observation, abstract conceptualisation, and active experimentation (Timm et al., 2011). Kramar (2009) divides methods by functionally-complementary perspective, as Tomić does, with the exception of experiential learning, which he omits. He further classifies methods to the spoken explanation method, lecture, conversation method, textual method, demonstration method, problem method, and case method. The classification of Starc, Rodica and Konda (2015) is a combination of Kramar's and Tomićs models, with some methods bearing the same semantic meaning but named differently (e.g., laboratory method vs. experimental method); therefore, the only addition is the project method. Other authors (Brook, Pedler, \& Burgoyne, 2012; Ivon \& Kuščević, 2013; Mijoč, 1995, 2007, 2009) mention action learning, project method, case-study method, experiential learning, role-play, simulation, structured practice, group interaction, and guided visualisation.

Furthermore, teaching forms can be defined as social forms in which the learning process, that is teaching and learning, takes part (Tomić, 2000). Teaching forms in the German context can be divided into frontal teaching/direct instruction, group work, work in pairs and individual work (Garotti, 2015; Jank \& Meyer, 2006; Kiper, Meyer, \& Topsch, 2002). Authors in didactic theory classify them into frontal teaching form/direct instruction and indirect form/ autonomous work of students (Kadum-Bošnjak, 2012; Kramar, 2009; Strmčnik, 2001; Tomić; 2000). The indirect form consists of learning in groups/group work, work in pairs and individual work (Kramar, 2009; Rot Vrhovec, 2015; Starc et al., 2015; Strmčnik, 2001; Tomić, 2000; Topolovčan, 2012). Group work, and thus participation in group activities, is the primary form of teaching in NFE (Eraut, 2004 \& Wenger, 1998, in Kiilakoski \& Kivijarvi, 2015). Some authors (Javornik Krečič et al., 2014; Stanković \& Blažić, 2015) add programmed instruction, which runs without direct instruction, mostly as individual work. Teaching methods and forms are necessary not only for the diversification of education, but also to achieve deeper understanding and independent, critical and creative learning (Javornik Krečič et al., 2014). It is believed that the choice of teaching forms and methods (e.g., more practical learning, omitting ex-cathedra) might even improve the learner's career success (Pavlin, 2014).

Prevailing methods and forms of teaching in youth organisations are peer learning, experiential learning (Bužinkić, Ćulum, Horvat, \& Kovačić, 2015; del Felice \& Solheim, 2011), interactive and participatory learning, and learning in groups (Fennes \& Otten, 2008). Participative learning is defined as learning that recognises and values experience (Sapin, 2009); as an approach in adult learning 
that encompasses three components: using participants' experiences as a basis for learning, valuing these experiences throughout the programme, and encouraging participants to learn from each other (Sapin \& Waters, 1990). Methods that are classified as appropriate in the spectrum of youth work are active learning, experiential learning, learning from each other/participatory learning, passing on information and illuminating (Sapin, 2009). In youth organisations, young people learn through workshops, trainings, debates etc. (Souto-Otero, 2016). They learn through the methods of NFE on planned trainings, from guidance of experienced workers, from educational materials, in learning-by-doing, and though the aforementioned peer learning and experiential learning (Del Felice \& Solheim, 2011). Beside NFE, young people also learn through informal learning, which is perceived as spontaneous learning, mostly based on interaction with peers outside of planned activities (Del Felice \& Solheim, 2011).

There is a plethora of research on teaching methods and forms (Allen et al., 2011; Bell, 2010; Brook et al., 2012; Garotti, 2015; Gojkov et al., 2015; Ivon \& Kuščević, 2013; Jank \& Meyer, 2006; Javornik Krečič et al., 2014; KadumBošnjak, 2012; Kramar, 2009; Kiper et al., 2002; Mijoč, 1995, 2007, 2009; Radovan, 2013; Rot Vrhovec, 2015; Stanković \& Blažić, 2015; Starc et al., 2015; Stes \& Petegem, 2014; Strmčnik, 2001; Struyven et al., 2010; Timm et al., 2011; Tomić, 2000). It is acknowledged that there are learning processes, non-formal learning and NFE taking place in youth work inside youth organisations (European Commission, 2000, 2012; Fennes \& Otten, 2008; Kuhar \& Leskošek, 2008; Souto-Otero, 2016). Furthermore, some studies illuminate the field of teaching methods and teaching forms in youth organisations (i.e., Bužinkić et al., 2015; del Felice \& Solheim, 2011; Fennes \& Otten, 2008; Sapin, 2009; Souto-Otero, 2016). However, there are gaps in the detailed research of teaching methods and forms in Slovenian youth organisations/youth councils.

\section{Primary objective}

The present paper explores the didactic aspects of NFE in youth work. It aims to contribute to a better understanding of teaching methods and teaching forms in NFE in national youth councils in Slovenia. The objective is to prepare the taxonomy of NFE on a national level that is conducted by qualified educators and carried out in national youth councils in Slovenia.

\section{Research questions}

The following research questions guided the research:

- What teaching forms can be found in NFE for youth in youth councils on a national level in Slovenia? 
- What teaching methods can be found in NFE for youth in youth councils on a national level in Slovenia?

\section{Research methodology}

\section{Research sample}

- Population: all NFE for youth in youth councils on a national level and in youth councils on a local level.

- $\quad$ Sample: selected NFE for youth in youth councils on a national level.

- Selection criteria of NFE: duration (more than one day), date of NFE (last conducted NFE), level (national), competence of educators (qualified for conducting NFE in youth sector).

There was only one youth council on a national level at the time of the research: Mladinski svet Slovenije, National Youth Council of Slovenia (MSS). It is defined in legislation (Act Amending Youth Councils Act, 2010; Youth Councils Act, 2000) as a voluntary association of national youth organisations, which have a status of an organisation in the public interest in the youth sector in accordance with the act (Public Interest in Youth Sector Act, 2010). One of the policy areas of MSS is youth work. NFE and training together with the enhancement of competencies are among the main objectives.

According to the selection criteria, the selected NFE is Usposabljanje za trenerje $v$ mladinskem delu (Training for Trainers in Youth Work) that took place between March $31^{\text {st }}$ and April $3^{\text {rd }}, 2016$ in Brežice, Slovenia. It was described as an intensive four-day training. There were 23 participants and four educators, known as trainers. Their aim was to train the participants for preparation, execution and evaluation of trainings in youth work and to prepare them for working with young adults.

\section{Data collection (methods)}

- The research paradigm: qualitative.

- Data collection technique: semi-structured interviews.

- Instrument: the list of questions for semi-structured interviews.

The list of questions was peer-reviewed by an expert and based on a synthesis of several models. The classification of the teaching methods was synthesised by Allen et al., 2011; Bell, 2010; Brook et al., 2012; Ivon \& Kuščević, 2013; Kramar, 2009; Mijoč, 2007; Timm et al., 2011; Tomić, 2000; Starc et al., 2015. The classification of teaching forms was synthesised by authors Garotti, 2015; 
Jank \& Meyer, 2006; Javornik Krečič et al., 2014; Kiper et al., 2002; Kramar, 2009; Rot Vrhovec, 2015; Stanković \& Blažić, 2015; Starc et al., 2015; Strmčnik, 2001; Tomić, 2000; Topolovčan, 2012. The list of questions was divided into four sections, and it comprised 19 questions, with sub-questions.

\section{Participants}

For a better understanding of the problem and for validity and reliability purposes, the interviews were conducted with the same instrument on three different groups of persons (three sources of data); that is with data source triangulation (Easterby-Smith, Thorpe \& Lowe 2007; Devetak, Glažar, \& Vogrinc, 2010; Vogrinc 2008). The three groups of interviewees are presented in Table 1. Persons were selected by the time criterion, namely those who responded to the invitation first. The number of interviews was determined by the rule of theoretical saturation (Flick, 2006), which is the reason for a difference between the planned number of interviews and the number of conducted interviews as seen in Table 1.

Table 1

Participants of the research - interviewees

\begin{tabular}{|c|c|c|c|}
\hline Level & $\begin{array}{l}\text { Planned no. } \\
\text { of Interviews }\end{array}$ & $\begin{array}{l}\text { No. of conducted } \\
\text { interviews }\end{array}$ & The position of interviewees \\
\hline Organiser & $1-2$ & 2 & $\begin{array}{l}1 \text { person, responsible for NFE at MSS } \\
1 \text { person, responsible for educating } \\
\text { trainers at MSS }\end{array}$ \\
\hline Trainer & $1-2$ & 2 & $\begin{array}{l}2 \text { persons, qualified for conducting } \\
\text { NFE in youth sector by MSS criteria, } \\
\text { who were trainers at the last NFE event } \\
\text { on a national level at MSS, which lasted } \\
\text { more than } 1 \text { day }\end{array}$ \\
\hline Participant & $2-3$ & 2 & $\begin{array}{l}2 \text { persons, who were participants at the } \\
\text { last NFE event on a national level at } \\
\text { MSS, which lasted more than } 1 \text { day and } \\
\text { was conducted by qualified trainers }\end{array}$ \\
\hline
\end{tabular}

\section{Research conduct}

- $\quad$ Data collection period: between $14^{\text {th }}$ and $31^{\text {st }}$ July 2016.

- The interviews were conducted individually with each person at the same location (at MSS) with the exception of two interviews taking place elsewhere. The tape recordings last from 27 minutes to 44 minutes, with the average duration of 36 minutes. 


\section{Data analysis}

Interviews were recorded and transcribed verbatim, the result is nearly 100 pages of transcriptions. The data analysis method is qualitative content analysis, with the method of grounded theory (Easterby-Smith et al., 2007; Vogrinc, 2013). Transcriptions were systematically analysed with coding and categorising. A flexible deductive approach was used, in which abstract notions served as a basis; they were checked on empirical data, but in accordance with flexibility new codes and categories were added in the process of analysis (Vogrinc, 2013). Therefore, some categories were formed subsequently (Marvasti, 2004). Open coding, axial coding, and selective coding by Glasser and Strauss were used (Easterby-Smith et al., 2007; Marvasti, 2004). No special software for qualitative analysis was used for data analysis: only Word and Excel.

The study was approved by the Ethics Commission of the Faculty of Education, University of Ljubljana.

\section{Results and discussion}

\section{Results}

A total of 493 codes were assigned to the data: 352 codes to the teaching methods and 141 codes to the teaching forms. There are 12 categories and 14 subcategories in the data; two categories and four subcategories for the $1^{\text {st }}$ research question on teaching forms (theme: teaching forms) and 10 categories and 10 subcategories for the $2^{\text {nd }}$ research question on teaching methods (theme: teaching methods). The list of teaching methods and forms is not an exhaustive list.

The results indicate the presence of frontal teaching form/direct instruction as well as indirect forms/autonomous work of students in selected NFE in (MSS). The taxonomy of teaching forms is presented in Figure 1.

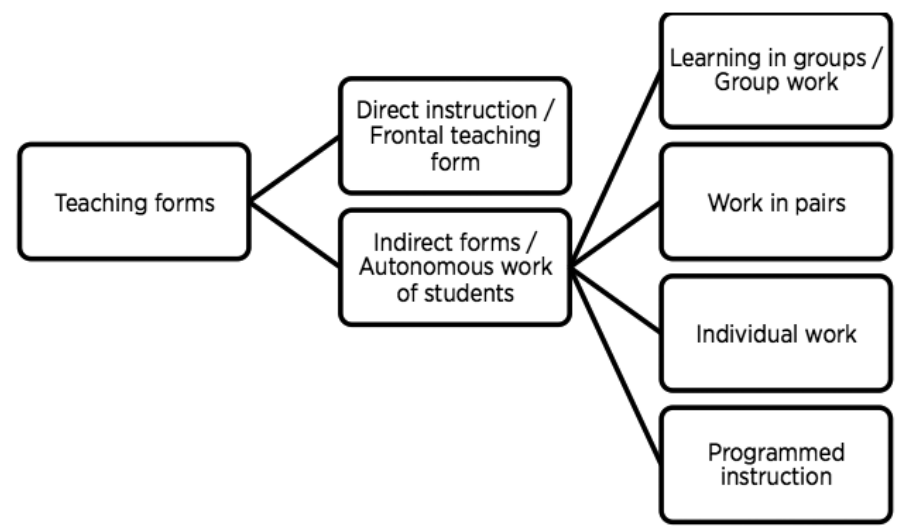

Figure 1. Taxonomy of teaching forms (categories and subcategories) in selected NFE in National Youth Council of Slovenia (MSS). 
The results indicate that teaching methods in selected NFE in MSS include the methods presented in Figure 2. The classification of subcategories and further taxonomy is illustrated in Figure 3 (for verbal-textual methods), Figure 4 (for illustrative-demonstration methods) and Figure 5 (for support methods).

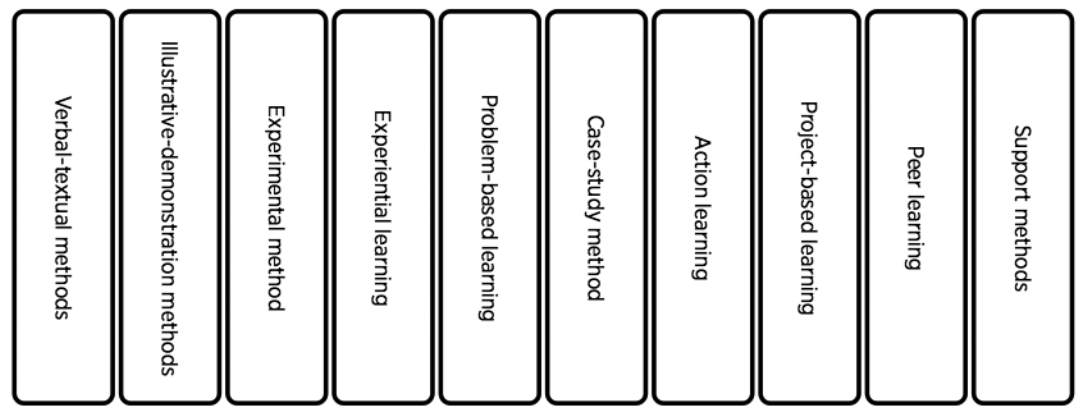

Figure 2. Taxonomy of teaching methods (categories) in selected NFE in MSS.

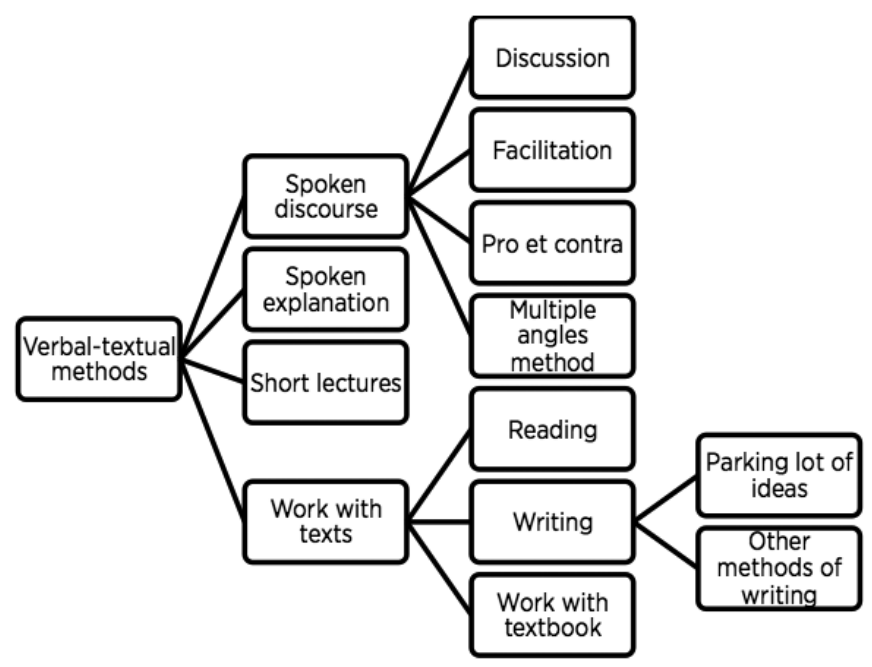

Figure 3. Taxonomy of verbal-textual methods (subcategories) in selected NFE in MSS. 


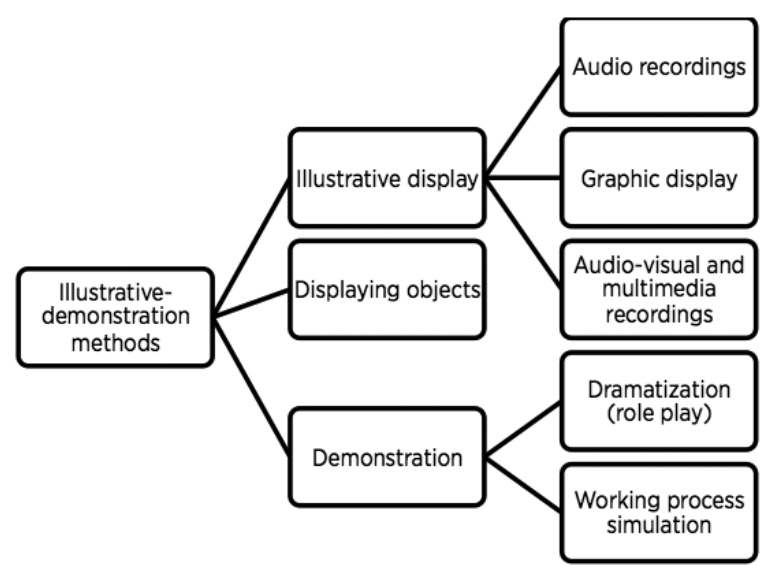

Figure 4. Taxonomy of illustrative-demonstration methods (subcategories) in selected NFE in MSS.

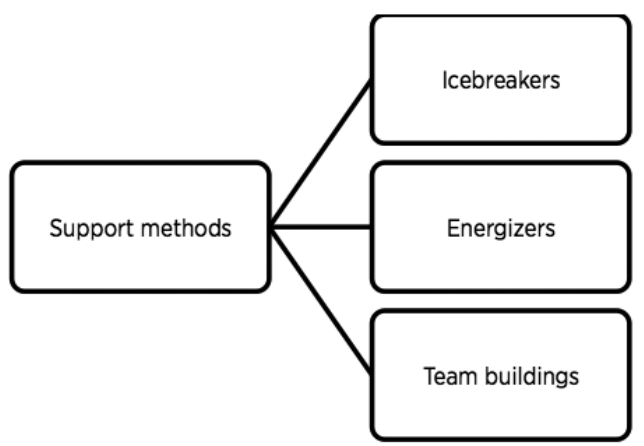

Figure 5. Taxonomy of support methods (subcategories) in selected NFE in MSS.

Teaching forms in selected NFE for youth in youth councils the on national level - in National Youth Council of Slovenia (MSS)

Firstly, it should be noted that the selection of teaching forms and methods in NFE in MSS depends on trainers; according to their internal recommendations, methods and forms for all learning styles should be included. In selected NFE in MSS, the frontal teaching form/direct instruction and indirect forms/autonomous work of students are present. Direct instruction is represented in a small measure. As illustrated by the statement of the interviewee on the participant level (Ipart) about the presence of this teaching form: 'Very little, but there was also a bit of that.' Furthermore, the organisers recommend limiting direct instruction; and using it only for covering theoretical aspects. 
This is also consistent with theory, since direct instruction is more appropriate for children and younger pupils, who need systematic guidance in comparison with adults with more work- and life experience (Mijoč, 2009). The participants of selected NFE can be defined as older adolescents or young adults, therefore, according to their characteristics, direct instruction is less suitable for them.

Indirect teaching forms are more stressed, and among them learning in groups is the most important, with the biggest part of selected NFE conducted as such. The key teaching form in the selected NFE is learning in groups, corresponds with teaching form present in youth clubs (Eraut, 2004 \& Wenger, 1998, in Kiilakoski \& Kivijarvi, 2015) and with suitable forms in NFE (Starc et al. 2015). As stated by the interviewee on the trainer level (Itrain): 'Well, yes, there was a lot of group work [...] it was mostly that'. The groups were of various sizes and consisted of 3 to 24 members. They were structurally different formed randomly, by instructions or with self-initiative according to the interest. The groups were not permanent; on the contrary, they changed constantly, with participants undertaking different roles in these groups. The interviewees report that group work made them participate more actively; some of them state responsibility towards other group members as the source of motivation. At the same time in this teaching form there is less responsibility on the educator alone to impart knowledge and more on the group and on the individual. Learning in groups encourages communication skills, it makes participants more motivated and consequently more effective, and at the same time raises their responsibility for the results of joint work (Kramar, 2009).

Work in pairs was present in selected NFE in MSS, but to a limited extent. Individual work was present to a limited extent as well. It took place after the completion of a specific content section, in which the participants were expected to write their reflections. Furthermore, it was present when the participants had the task of preparing a presentation on their own. Finally, it can be said that programmed instruction was present if defined as a teaching form with prepared instructions where the individual solves the task without the educator's help. Such a teaching form was present; however, without pre-programmed software, but through a pre-defined learning sheet. As stated by Itrain: 'And basically there was no need for an explanation [...] there were questions on [the learning sheet] that guided them'. That is contrary to some definitions (Stanković \& Blažič, 2015) which associate programmed instruction mainly with computers and refer to it as computer-assisted instruction. Programmed instruction results in increased participation and in individualisation of learning speed (Javornik Krečič et al., 2014). 


\section{Teaching methods in selected NFE for youth in youth councils on the} national level - in the National Youth Council of Slovenia (MSS)

The results indicate the presence of the following teaching methods in the selected NFE in MSS: verbal-textual methods, illustrative-demonstration methods, experimental method, experiential learning, problem-based learning, case-study method, action learning, project-based learning, peer learning and support methods.

Firstly, verbal-textual methods in our research can be divided into four subcategories (as presented in Figure 3). The interviewees mention spoken explanation, which is used as the additional explanation of content and for interpretation of definitions. The theory is that a well-defined spoken explanation is suitable for theoretical content and for topics that learners would not be able to assimilate to such an extent themselves (Kramar, 2009). Some researchers (e.g., Sapin, 2009) classify passing on information and illuminating as appropriate teaching methods, which is not confirmed by our research, as passing on information and illumination in the sense of spoken explanation and lectures are less represented in the selected NFE. Lectures are less present and appear mostly as short lectures. As illustrated by Itrain: 'And there was a small part of theory inside the programme which lasted for 10 minutes.' Lectures are mainly used for giving theory and for unifying knowledge before further work with other methods. Therefore, the research confirms the theory (Kramar, 2009) that they are used for that transmission of content, information and viewpoints that learners shall become acquainted with and adopt. The specialty of the selected NFE is that lectures exist in reversible format, where the participants prepare content and present it to other participants and to trainers in the plenary, therein shifting the roles.

Furthermore, spoken discourse is present in all forms, with participants interacting with one another and through participants' and trainers' interaction, where questions are raised, and feedback is given through active participation. Great importance is attributed to the continuous openness for questions by trainers and the active participation of participants. Trainers often assume the role of facilitators, only facilitating the discourse with participants being a source of knowledge and information. Other methods of spoken discourse, in addition to discussion and facilitation, include 'multiple angles method' and 'pro-et-contra'. In the verbal methods in the selected NFE, there is a strong focus on dialogue and interaction, and less on monologue.

Finally, work with texts is present throughout the process. It is present as reading (reading of texts; such as definitions appearing on several sheets that need to be assembled into a meaningful whole), writing (writing presentations 
of products; recording thoughts, opinions and reflections; writing plans for work tasks) and didactic work with textbooks. In the latter case, the participants receive a book that helps them with their task of preparing their own workshop. As illustrated by the interviewee on an organiser level (Iorg): 'All the participants get [...] a manual for trainers in youth work [...] we provide it'. The writing method includes 'parking lot of ideas', where the participants can write their reflections on a flip chart during the whole day, with discussion following in the evening evaluation. To sum up, work with texts is manifested in reading and in preparation of written material with the constant emphasis on self-activation (Kramar, 2009), as the texts in the selected NFE only represent a basis for participants' activation.

Secondly, illustrative-demonstration methods are also represented in the selected NFE. An illustrative display is manifested through audio recordings, graphic display ('photo-speech method', illustrations, pictures, schematics, etc.) and watching audio-visual and multimedia recordings (films, YouTube recordings, etc.). Displaying objects was present through showing different objects and items (balls, flowers, facilitation kit, etc.). As stated by Itrain: 'I've learned what Neuland markers are. The co-trainer actually showed the facilitation kit.' Demonstration methods were mostly present through dramatisation and role play, but there was also a working process simulation. An example of dramatisation was described by Ipart: 'She had a demonstration about what good public performance looks like and she was actually playing a teacher. And she was playing a teacher who cannot speak well publicly'. The present illustrative-demonstration methods encouraged the perception of participants through the activation of several senses (Tomić, 2000).

Thirdly, the experimental method is also represented in the selected NFE. There was certain bias on the answers to this question; therefore, the results are not entirely valid. There were experiments in a social science context, but there was no laboratory testing of natural phenomena or laboratory work in a natural science context (Tomić, 2000). Such experiments can be illustrated by two examples. Firstly, by simulation exercises in which a certain case was played out three times, each time with different parameters. The second example was the experiment on learning styles, in which participants were divided into three groups with the goal of folding t-shirts using a new technique. One group had audio-recording instructions, the second group had video-recording instructions, and the third group had video-recording instructions together with a t-shirt for testing purposes.

Fourthly, experiential learning was a method that was mentioned by the interviewees most often. It was presented as omnipresent and referred to as 
the key teaching method in the selected NFE as well as all NFE in MSS and in youth work in general. Iorg stated: 'That is the basic guideline for NFE, at least in the MSS context'. The process of experiential learning follows all four phases of Kolb's circular model, as illustrated by Iorg: 'The themes that are learned and presented there are simultaneously tested in practice. An example mentioned by all interviewees is the part of the selected NFE in which the participants had to independently plan and conduct one workshop after learning the basics of theory. They observed their own and their colleagues' experiences, received and gave feedback at the same time, and implemented it into their own presentation. The research confirms that experiential learning originates in a primary experience and offers active learning, which enables greater internalisation of knowledge, simultaneously increasing its importance and prolonging its memorisation (Timm et al., 2011).

Fifthly, project-based learning can be found in the selected NFE; however more in terms of short projects, covering a limited amount of time, executed within NFE. To exemplify, the participants worked in groups to prepare a plan for a four-day seminar, each covering a certain aspect of the seminar that they had to conduct and perform individually. As illustrated by Iorg: '... a kind of project work, where the participants form an activity on their own, they execute it. and the trainer only serves as a mentor in this process. This is in accordance with the definition of project-based learning in education by Mijoč (2007) as a process in which an individual or a group chooses a problem which they examine, analyse, solve and present the results in front of the group.

Furthermore, the problem method with problem-based learning was present as the participants received specific problems from the practice to solve. They worked in groups to actively resolve complex and real problems (Allen et al., 2011), to which they had to apply all their knowledge and experience. Such learning is perceived as the highest form of learning as it is not only a reproduction of knowledge, but a creative transformation and application of priorknowledge and experience to new or modified situations (Javornik Krečič et al., 2014). The problem method in the selected NFE can be seen as an independent method or as a part of experiential learning. That also applies to the case-study method in the selected NFE, which is strongly intertwined with experiential learning.

The next teaching method present was action learning. In part of the selected NFE, the participants had to work with peers, perform actions, and reflect upon solutions, which is consistent with Revans' definition of action learning (Brook et al., 2012). Both action learning and the case-study method can be categorised as adult education methods, because they assume the participants 
can draw from their own experience, interpersonal relations, and life-situations (Mijoč, 2009). Despite the fact that some participants in the selected NFE might not yet be defined as adults, they fit the categories of younger adults and active citizens (participating in civil society organisations) and, therefore, possess sufficient experience for such methods. Furthermore, problem-based learning, case-study method and action learning are all very intertwined in the selected NFE; therefore, it is difficult to distinguish among them. Primarily, they are all strongly connected with experiential learning, which can be seen as their umbrella method in many aspects. The dilemma of many expressions for similar concepts is also highlighted by other researchers. For example, Mijoč (2007) claims that the project method is often connected with case-study, problem learning, project learning, experiential learning, etc.

Moreover, support methods that were present in the selected NFE can be divided into three sections: icebreakers, energisers, and team buildings. Iorg states: 'Almost every workshop has an energiser or an icebreaker for the participants... as we really want them to be present there.' For example, the interviewees mention building with Lego bricks as a team builder and different icebreakers for warming up. Support methods used in the selected NFE aim in helping participants merge into groups, connecting them, and gaining their attention. This is in accordance with Kane (2007), who claims that a good icebreaker can improve the learning environment, encourage socialisation and help participants relax.

Finally, peer learning was also present in the selected NFE. It can be seen as a component of NFE although it is more often present in less structured environments of informal learning (del Felice \& Solheim, 2011). However, our research does not explore informal learning; therefore, informal aspects of peer learning are not covered. Peer learning in the selected NFE is present as the transmission of knowledge between the participants and the trainers within other methods (e.g., in discussion); the trainers provide an environment that encourages such learning. As illustrated by Itrain: 'There is a lot of learning from each other. Peer learning can be grouped in the broader concept of participative learning (Sapin, 2009), also referred to as 'participatory learning' (Fennes \& Otten, 2008). In the selected NFE participative learning can be found in each teaching method and form. Its presence can be felt through the wording of the interviewees. This can be illustrated by the statements of Itrain: 'Altogether, it was very [...] inclusive, interactive, reflexive.' and Ipart: 'We had constant interaction with the trainers, we cooperated [...]. There were constant calls for feedback. 


\section{Conclusion}

Youth in youth organisations learn through seminars, courses (del Felice \& Solheim, 2011) and trainings (Souto-Otero, 2016), in the categories of which the selected NFE can be placed. The present research confirms that learning in the selected NFE in the National Youth Council of Slovenia (MSS) is participative, interactive, inclusive and student-focused; with central concepts of experiential learning and learning in groups (Bužinkić et al., 2015; Fennes \& Otten, 2008; Sapin, 2009; Sapin \& Waters, 1990).

Learning in groups is seen as the primary teaching form in the selected NFE in MSS; however, individual work, work in pairs, programmed instruction, and direct instruction (which is the least represented) are also present. The central and omnipresent teaching method is experiential learning. Problem-based learning, the case-study method, action learning and project-based learning are intertwined and connected to the experiential learning method, which can be seen as their umbrella method. Other methods include verbaltextual methods (spoken discourse, spoken explanation, short lectures, and work with texts), illustrative-demonstration methods (illustrative display, displaying objects and demonstration), experimental methods in social science context, peer learning and support methods (icebreakers, energisers, and team building). Participative learning is typical for youth work, and in the selected NFE it can be found throughout every teaching method and form.

\section{Limitations}

The selected NFE took part four months before the interviews; therefore, some errors in recall of the interviewees are possible. Furthermore, the selected NFE was specific, as its aim was to train the participants to conduct the similar NFE on their own. Consequently, they had better knowledge of teaching methods and forms. At the same time, the selected NFE was more methodologically diverse, as the trainers' aim was to present as many methods in forms in practice as possible. Moreover, the list of questions was based on a synthesis of several models and peer-reviewed by one expert only, due to the situational limitations. More peer-reviews might have contributed to a better quality of the instrument. Finally, the author entered the research with certain knowledge of NFE in MSS, and she met with some interviewees before the research.

\section{Applicability of the results and further research}

The results of the research are applicative in the didactic spectrum of NFE in youth work and in the wider didactic spectrum of adult learning. 
Nevertheless, certain parts of the research can be applied in practice in work with young people inside the formal-education system. Implications for further research include teaching methods and forms in NFE inside the wider youth sector in Slovenia and a comparative analysis of national youth councils in the international context. Furthermore, a quantitative study would be a needed addition to the present research.

\section{Acknowledgements}

The author wishes to thank MSS, all the interviewees, the supporter of

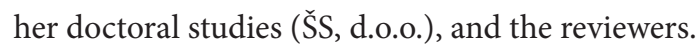

\section{References}

Act Amending Youth Councils Act (ZMS-A) (2010). Official Gazette of the RS, No. 42 (28. 5. 2010).

Allen, D. E., Donham, R. S., \& Berhhard, S. A. (2011). Problem-based learning. New Directions for Teaching \& Learning, 128, 21-29.

Bell, S. (2010). Project-based learning for the 21st century: Skills for the future. Clearing House, 83(2), $39-43$.

Bessant, J. (2004). Mixed messages: Youth participation and democratic practice. Australian Journal of Political Science, 39(2), 387-404.

Boeren, E. (2011). Gender differences in formal, non-formal and informal adult learning. Studies in Continuing Education, 33(3), 333-346.

Brook, C., Pedler, M., \& Burgoyne, J. (2012). Some debates and challenges in the literature on action learning: The State of the art since revans. Human Resource Development International, 15(3), 269-282. Bužinkić, E., Ćulum, B., Horvat, M., \& Kovačić, M. (2015). Youth work in Croatia: Collecting pieces for mosaic. Child and Youth Services, 26(1), 30-55.

Coussée, F. (2009). The relevance of youth works history. In G. Verschelden, F. Coussée, T. Van de Walle \& H. Williamson (Eds.), The history of youth work in Europe (pp. 7-11). Paris: Council of Europe Publishing.

Del Felice, C., \& Solheim, L. (2011). Youth organisations as learning organisations: Exploring special contributions and challenges. Development in Practice, 21(8), 1094-1108.

Devetak, I., Glažar, A. S., \& Vogrinc, J. (2010). The role of qualitative research in science education. Eurasia, 6(1), 77-84.

Easterby-Smith, M., Thorpe, R., \& Lowe, A. (2007). Raziskovanje v managementu [Management research: An introduction]. Koper: Fakulteta za management.

European Commission (2000). Commission staff working paper: A memorandum on lifelong learning. Retrieved from http://tvu.acs.si/dokumenti/LLLmemorandum_Oct20oo.pdf European Commission (2012). Council recommendation of 20 December 2012 on the validation of non-formal and informal learning. Official Journal of the EU, No. 398 (22. 12. 2012). 
Fennes, H., \& Otten, H. (2008). Quality in non-formal education and training in the field of European youth work. Brussels: The European Union - Council of Europe youth partnership in Salto-youth.

Flick, U. (2006). An introduction to qualitative research. London, Thousand Oaks, New Delhi: SAGE Publications.

Gaber, S., \& Mojškerc, N. (2014). E-participation as a possible upgrading of representative democracy. Teorija in praksa, 51(6), 1242-1262.

Garotti, F. R. (2015). Deutschunterricht an italienischen Universitäten für Studierende des Deutschen als Fremdsprache [German lessons at Italian universities for students of German as a foreign language]. German as a Foreign Language, 3(2015), 80-96.

Gojkov, G., Stojanović, A., \& Gojkov-Rajić, A. (2015). Didactic strategies and competencies of gifted students in the digital era. CEPS Journal, 5(2), 57-72.

Haralambos, M., \& Holborn, M. (2005). Sociologija: Teme in pogledi [Sociology: Themes and perspectives]. Ljubljana: DZS.

Ivon, H., \& Kuščević, D. (2013). School and the cultural heritage environment: Pedagogical, creative and artistic aspects. CEPS Journal, 3(2), 29-50.

Jank, W. \& Meyer, H. (2006). Didaktični modeli [Didactic models]. Ljubljana: Zavod RS za šolstvo. Javornik Krečič, M., Rutar Leban, T., \& Kelava, P. (2014). Značilnosti pouka v srednjih strokovnih in poklicnih šolah z vidika učiteljev in dijakov [The features of teaching in upper secondary vocational education and training from the perspective of teachers and students]. Šolsko polje, 25 (1/2), 31-54.

Kadum-Bošnjak, S. (2012). Suradničko učenje [Cooperative learning]. Metodički ogledi, 19(1), 181-199. Kane, L. (2007). Educators, learners and active learning methodologies. International Journal of Lifelong Education, 23(3), 275-286.

Kiilakoski, T., \& Kivijarvi, A. (2015). Youth clubs as spaces of non-formal learning: Professional idealism meets the spatiality experienced by young people in Finland. Studies in Continuing Education, $37(1), 47-61$.

Kiper, H., Meyer, H., \& Topsch, W. (2002). Einführung in die Schulpädagogik [Introduction to school education]. Berlin: Cornelsen Scriptor.

Kolarič, Z., \& Rakar, T. (2010). Obseg, struktura in vloga/funkcija slovenskih civilno-družbenih organizacij: raziskava Indeks civilne družbe: študija primera, dimenzija, raven organizacij [The scope, structure and role / function of Slovenian civil society organizations: Research civil society index: Case study, dimension, level of organizations]. Ljubljana: Inštitut Republike Slovenije za socialno varstvo.

Kramar, M. (2009). Pouk [Classes]. Nova Gorica: Educa, Melior.

Kuhar, M., \& Razpotnik, Š. (2011). Uvod. In M. Kuhar \& V. Leskošek (Eds.), Okviri in izzivi mladinskega dela $v$ Sloveniji [The frames and challenges of youth work in Slovenia] (pp. 7-9). Ljubljana: Pedagoška fakulteta.

Kuhar, M., \& Leskošek, V. (2008). Mladinsko delo na lokalni ravni: primerjalna analiza petih držav [Youth work at local level: Comparative analysis of five countries]. Socialna pedagogika, 12(4), 325-343. Lebeničnik, M., Pitt, I., \& Starčič Istenič, A. (2015). Use of online learning resources in the development of learning environments at the intersection of formal and informal learning: The student as 
autonomous designer. CEPS Journal, 5(2), 95-113.

Marentič-Požarnik, B. (2014). Psihologija učenja in pouka [Psychology of learning and teaching]. Ljubljana: DZS.

Mijoč, N. (1995). Izkustveno učenje - enakovredna pot do znanja [Experiential learning - an equal path to knowledge]. Andragoška spoznanja, 1(1/2), 39-41.

Mijoč, N. (2007). Projektna metoda v izobraževanju [Project method in education]. Andragoška spoznanja, 13(3), 19-25.

Mijoč, N. (2009). Nekateri temeljni pojmi z vidika andragoške didaktike [Some basic concepts from the perspective of andragogical didactics]. Andragoška spoznanja, 15(1), 58-64.

Marvasti, A. B. (2004). Qualitative research in sociology. London, UK: Sage.

Pantea, M. C. (2012). Mapping of competences needed by youth workers to support young people in international learning mobility projects. Brussels: Youth Partnership.

Public Interest in Youth Sector Act (ZJIMS) (2010). Official Gazette of the RS, No. 42 (28. 5. 2010).

Pavlin, S. (2014). The role of higher education in supporting graduates' early labour market careers. International Journal of Manpower, 35(4), 576-590.

Radovan, M. (2013). Metode v izobraževanju odraslih [Methods in adult education]. Andragoška spoznanja, 19(4), 5-8.

Rakar, T., Deželan, T., Vrbica, S. Š., Kolarič, Z., Črnak Meglič, A., \& Nagode, M. (2011). Civilna družba $v$ Sloveniji [Civil society in Slovenia]. Ljubljana: Uradni list Republike Slovenije.

Rot Vrhovec, A. (2015). 2015. Forms of cooperative learning in language teaching in Slovenian language classes at the primary school level. CEPS Journal, 5(3), 129-155.

Sapin, K., \& Waters, G. (1990). Learning from each other: A handbook for participative learning and community work learning programmes. Manchester, UK: The William Temple Foundation.

Sapin, K. (2009). Essential skills for youth work practice. London, UK: Sage.

Souto-Otero, M. (2016). Young people's views of the outcomes of non-formal education in youth organisations: Its effects on human, social and psychological capital, employability and employment. Journal of Youth Studies, 19(7), 938-956.

Stanković, Z., \& Blažič, M. (2015). Didactical model of instruction based on the application of educational software. Didactica Slovenica - Pedagoška Obzorja, 3o(1), 21-45.

Starc, J., Rodica, B., \& Konda, I. (2015). The significance of teaching methods/forms and organizational forms as important elements for the professional development in the education and training of managers involved in tourism. Informatologia, 48(1/2), 48-61.

Stes, A., \& Van Petegem, P. (2014). Profiling approaches to teaching in higher education: A cluster-analytic study. Studies in Higher Education, 39(4), 644-658.

Strmčnik, F. (2001). Didaktika: Osrednje teoretične teme [Didactics: The central theoretical themes]. Ljubljana: Znanstveni inštitut Filozofske fakultete.

Struyven, K., Dochy, F., \& Janssens, S. (2010). Teach as you preach: The effects of student-centred versus lecture-based teaching on student teachers' approaches to teaching. European Journal of Teacher Education, 33(1), 43-64. 
Taft, J. K., \& Gordon, H. R. (2013). Youth activists, youth councils, and constrained democracy. Education, Citizenship \& Social Justice, 8(1), 87-100.

Timm, T., Birkenmaier, J., \& Tebb, S. (2011). The experiential community assessment project: Integrating social work practice skills. Journal of Community Practice, 19(2), 175-188.

Tomić, A. (2000). Izbrana poglavja iz didaktike [Selected topics from didactics]. Ljubljana: Center za pedagoško izobraževanje Filozofske fakultete.

Topolovčan, T. (2012). Communication and teaching and learning methods (social work forms) in multimedia online distance education. Practice and Theory in Systems of Education, 7(2), 203-209.

UNESCO (1993). Review of the international standard classification of education (ISCED). Retrieved from http://unesdoc.unesco.org/images/ooog/ooo953/o95389eb.pdf

Vogrinc, J. (2008). Pomen triangulacije za zagotavljanje kakovosti znanstvenih spoznanj kvalitativnega raziskovanja [The importance of triangulation for ensuring the quality of scientific findings of the qualitative research]. Sodobna pedagogika, 59(5), 108-122.

Vogrinc, J. (2013). Kvalitativno raziskovanje na pedagoškem področju [Qualitative research in the pedagogical field]. Ljubljana: Pedagoška fakulteta.

Youth Councils Act /ZMS/ (2000). Official Gazette of the RS, No. 70 (8. 8. 2000).

Žagar, I. Ž., \& Kelava, P. (2014). Introduction. In I. Ž. Žagar \& P. Kelava (Eds.), From formal to non-formal: Education, learning and knowledge (pp. ix-xiv). Newcastle upon Tyne, UK: Cambridge Scholars Publishing.

\section{Biographical note}

Vesna Miloševič Zupančič is a PhD student of Human Resources and Organisational Studies at the Faculty of Social Sciences at the University of Ljubljana. She graduated at the Faculty of Arts at the University of Ljubljana and she holds a master's degree from the Faculty of Management at the University of Primorska. She is employed as Youth and Labour Market Expert at e-Studentski Servis (ŠS d.o.o.). Her research interests include competencies, youth organizations and non-formal education. 